\title{
Sexual maturation in free-ranging Chilabothrus angulifer (Serpentes: Boidae)
}

\author{
Tomás M. Rodríguez-Cabrera ${ }^{1}$, Javier Torres López², Ruben Marrero ${ }^{3}$, Ernesto Morell Savall ${ }^{4}$, \\ and Ana Sanz Ochotorena ${ }^{2}$ \\ ${ }^{1}$ Jardín Botánico de Cienfuegos, Pepito Tey, Cienfuegos, CP 59290, Cuba. E-mail: tomasmichel.rodriguez@gmail.com. \\ ${ }^{2}$ Departamento de Biología Animal y Humana, Facultad de Biología, Universidad de la Habana, La Habana, CP 10400, Cuba. \\ E-mail: javiertorres@fbio.uh.cu, anita@fbio.uh.cu. \\ ${ }^{3}$ División de Zoología de Vertebrados, Instituto de Ecología y Sistemática, La Habana, CP 11900, Cuba. E-mail: rubensherp89@ \\ gmail.com. \\ ${ }^{4}$ Área Protegida "Sabanas de Santa Clara", Empresa Nacional para la Conservación de la Flora y la Fauna, Santa Clara, Villa \\ Clara, CP 50199, Cuba. E-mail: ernestomorell68@ nauta.cu.
}

\begin{abstract}
Sexual maturation in free-ranging Chilabothrus angulifer (Serpentes: Boidae). The Cuban Boa ( $C$. angulifer) is the only boid snake in Cuba. It is the largest member of the genus, as well as the largest snake in the West Indies (> $400 \mathrm{~cm}$ in snout-vent length); as such, it is an iconic species of the Cuban herpetofauna. Although the snake's natural history is poorly known, several studies describe aspects of its reproductive biology in captivity. Herein we document the sizes and ages at which both sexes reach sexual maturity in nature, and show that the Cuban Boa reaches adulthood at a much smaller size than previously reported for captive snakes. Based on the limited information on the growth rate of $C$. angulifer in nature, males must reach breeding size after 3 years and females after 5 years.
\end{abstract}

Keywords: Cuba, Cuban Boa, endemic snake, minimum breeding size, reproductive biology, West Indies.

\section{Resumen}

Maduración sexual en Chilabothrus angulifer (Serpentes: Boidae) en la naturaleza. El majá de Santa María ( $C$. angulifer) es el único boido en Cuba. Es el mayor miembro del género, así como el mayor ofidio del Caribe Insular (> $400 \mathrm{~cm}$ de longitud hocico-cloaca), esto la convierte en una especie icónica de la herpetofauna cubana. A pesar de que su historia natural se conoce muy poco, varios estudios describen aspectos de su biología reproductiva en cautiverio. Aquí documentamos las edades y tallas con que ambos sexos alcanzan la madurez sexual en la naturaleza y mostramos que el majá de Santa María alcanza la adultez con una talla mucho más pequeña de lo que previamente

Received 5 February 2016

Accepted 5 September 2016

Distributed December 2016 
se ha reportado para especímenes de cautiverio. Basados en la escasa información sobre la tasa de crecimiento de $C$. angulifer en la naturaleza, los machos deben alcanzar la talla adulta después de los 3 años y las hembras después de los 5 años.

Palabras Clave: talla reproductora mínima, Cuba, serpiente endémica, biología reproductiva, Caribe Insular.

\begin{abstract}
Resumo
Maturidade sexual de Chilabothrus angulifer (Serpentes: Boidae) em estado selvagem. A jiboiacubana, Chilabothrus angulifer, é o único boídeo de Cuba. É a maior serpente do gênero e também das Índias Ocidentais (comprimento rostro-cloacal $>400 \mathrm{~cm}$ ); por essa razão, trata-se de uma espécie icônica da herpetofauna cubana. Apesar de sua história natural ser pouco-conhecida, diversos estudos descrevem aspectos de sua biologia reprodutiva em cativeiro. Documentamos aqui o tamanho e a idade em que ambos os sexos atingem a maturidade sexual na natureza e mostramos que essa serpente atinge a idade adulta com um tamanho muito menor do que previamente relatado para indivíduos cativos. Com base na informação limitada sobre a taxa de crescimento de $C$. angulifer na natureza, os machos atingem o tamanho reprodutivo após 3 anos, e as fêmeas, após 5 anos.
\end{abstract}

Palavras-chave: biologia reprodutiva, Cuba, Índias Ocidentais, jiboia-cubana, serpente endêmica, tamanho reprodutivo mínimo.

\section{Introduction}

The boid snake genus Chilabothrus Duméril and Bibron, 1844 comprises 12 species distributed in the Greater Antilles and Bahamas (Reynolds et al. 2013, 2016, Rodríguez-Robles et al. 2015). The endemic Cuban Boa, Chilabothrus angulifer (Cocteau and Bibron, 1840), is the only representative of the family Boidae in Cuba. It is the largest member of the genus, as well as the largest snake in the West Indies, exceeding $400 \mathrm{~cm}$ in snout-vent length (reviewed by Tolson and Henderson 1993, Henderson and Powell 2009). This primarily nocturnal snake is widespread in the Cuban Archipelago, occurring in a great variety of habitats from see level to above 1200 m elevation (Henderson and Powell 2009, RodríguezSchettino et al. 2010). It was evaluated as "Near Threatened" by the IUCN Red List of Threatened Species (Day and Tolson 1996), and retained in the same category in later evaluations (Polo-Leal and Rodríguez-Cabrera 2012). Also, this boa is listed under appendix II of CITES (e.g., UNEPWCMC 2014).
Although Chilabothrus angulifer is an iconic species of the Cuban herpetofauna, its natural history is poorly known; however, aspects of its reproductive biology in captivity have been described in several studies (Huff 1976, Nowinski 1977, Murphy et al. 1978, Bloxam and Tonge 1981, Tolson 1980, 1983, 1992, 1994, Tolson and Teubner 1987, Tolson and Henderson 1993, Morell et al. 1998, Polo-Leal and Moreno 2007, Morell 2009). Nevertheless, there are important gaps in our knowledge of the snake's reproductive biology, such as the size and age at which both sexes reach sexual maturity in nature. Tolson and Teubner (1987) suggested that reproductive maturity in females of some West Indian Chilabothrus (referred therein as Epicrates, but see work of Reynolds et al. 2013), is determined by body size and not age. These authors concluded that $C$. angulifer, given adequate size and lipid reserves, can reproduce as early as 3 years of age, and mentioned two females born in captivity that contained ovarian follicles more than $40 \mathrm{~mm}$ in diameter shortly after having reached this age. Moreover, Tolson (1992) and Tolson and 
Henderson (1993) argued that males can reproduce at shorter lengths (and presumably younger ages) than females, and reported a male that reached breeding size at 3 years, with snoutvent length (SVL) of $1613 \mathrm{~mm}$ and a body mass of $2960 \mathrm{~g}$.

However, these reports are based on captive specimens raised with ad libitum food and water (Tolson and Teubner 1987, Tolson 1992, Tolson and Henderson 1993); the energy expenditure of these individuals would be minimal because of confinement. There are no data on the sexual maturation of Chilabothrus angulifer in the wild (Tolson 1992, Tolson and Henderson 1993). We predict that in nature, the age at sexual maturity may vary individually in Cuban Boas and that it is directly correlated with feeding rates. Thus, snakes that are good hunters with access to plentiful trophic resources and that live in thermally stable environments (e.g., associated to hot caves with abundance of prey) will grow faster and therefore reach breeding size earlier. Herein we report the minimum size and age required for wild $C$. angulifer to reach sexual maturity, based on histological analysis of male reproductive organs, some morphological characters, estimates of growth rate, and direct observations of reproductive activity (i.e., copulation, parturition).

\section{Materials and Methods}

We kept male and female Chilabothrus angulifer in captivity to observe their reproductive behavior. Management of captive specimens largely followed the protocol of Tolson and Teubner (1987) and Tolson (1994), except for social grouping; we kept pairs isolated from conspecifics. The animals were surveyed twice a day (early in the morning and late in the afternoon) during the study period. We weighed juvenile snakes to the nearest $5 \mathrm{~g}$ and adults to the nearest $100 \mathrm{~g}$ with Pesola ${ }^{\circledR}$ spring scales. We also measured SVL and tail length with a string and a flexible measuring tape to the nearest 1 $\mathrm{mm}$. Smaller quantities of tissue such as fat were weighed with a Gram Precision ${ }^{\circledR}$ (BH-1200) electronic scale to the nearest $0.01 \mathrm{~g}$.

We also checked the reproductive maturity of a small, road-killed male Chilabothrus angulifer by removing the testes, epididymis, and vas deferens, and fixing them in buffered neutral formalin $(10 \%)$ for $72 \mathrm{~h}$. Then we transferred the samples to ethanol $(75 \%)$ for preservation. Histological preparations followed the methodology of Torre (1985). We sectioned the middle regions of the testes and the epididymis at a thickness of $5 \mu \mathrm{m}$ with a manual rotary microtome, and then stained the resulting sections with hematoxilin-eosin following the protocol of Ganter and Jollès (1970). We focused our observations mainly on epididymis because sperm cells are stored here after spermatogenesis (Estrada and Uribe 2002, Gribbins and Rheubert 2011).

We also observed a group of 15 small to medium-sized Cuban Boas (970-1840 mm SVL) from a hot cave at the Ecological Reserve "Mogotes de Jumagua" (2249'06" N, 8008'06" W; $20 \mathrm{~m}$ a.s.l.), Sagua La Grande, Villa Clara Province. They were monitored at 3 -month intervals during 2009. Recaptures of eight individuals (ranging in size from 970-1400 mm SVL) allowed estimates of growth rate (length) presented herein.

Geographic reference of all coordinates is WGS 84 . Means are presented \pm one standard deviation (SD).

\section{Results}

At 10:00 h, on 30 March 2008, we collected a male Chilabothrus angulifer (Figure 1A) of unknown age (1272 mm SVL, $158 \mathrm{~mm}$ tail length, $900 \mathrm{~g}$ ) on the ground of a semi-deciduous forest at Cariblanca $\left(22^{\circ} 03^{\prime} 54^{\prime \prime} \mathrm{N}, 7^{\circ} 40^{\prime} 19^{\prime \prime} \mathrm{W}\right.$, 200 m a.s.l.), Fomento, Sancti Spíritus Province. Despite its small size, we suspected that it was reproductively active. The snake was active by day (the species is primary nocturnal) at the onset of the reproductive season reported for this species (discussed below) and had well- 
developed pelvic spurs ( $>5.5 \mathrm{~mm}$ long, $2.5 \mathrm{~mm}$ wide at the base of claw vs. $2.5 \mathrm{~mm}$ long, 1.2 $\mathrm{mm}$ wide in females of equivalent size) (Figures $1 \mathrm{~B}, 2)$. We placed this individual into captivity together with a captive-born adult female approaching 8 years of age (2233 mm SVL, 217 $\mathrm{mm}$ tail length, $9525 \mathrm{~g}$ ). We recorded copulations on 19 April, 24 April, 2 May, and 8 May 2008. By 13 October 2008, the female gave birth to 13 neonates ranging in SVL from 593-646 mm, 53-67 mm in tail length, and 140-157 g. We estimated the gestation period to be anywhere between 169 and 177 days (approaching 6 month) owing to multiple copulations.

Around 08:00 h, on 27 April 2013, a mating aggregation of nine Chilabothrus angulifer (1 female, 8 males) was found by a local person inside a fallen hollow log of royal palm tree, Roystonea regia (Kunth) O. F. Cook, in a second-growth forest about $3 \mathrm{~km}$ west of Arimao $\left(22^{\circ} 04^{\prime} 25^{\prime \prime} \mathrm{N}, 8^{\circ} 20^{\prime} 25^{\prime \prime} \mathrm{W}, 50 \mathrm{~m}\right.$ a.s.1.), Cienfuegos Province. Although the local person killed the snakes, he told us the exact place of this finding so that we could examine them. All of the snakes were engaged in courtship (i.e., males intertwined around the female) when found (R. Martínez Jr., pers. comm.). The female was $1520 \mathrm{~mm}$ SVL (170 mm tail length) and weighed $1800 \mathrm{~g}$; a ventral incision revealed two mature ovarian follicles about $100 \mathrm{~mm}$ long. The males ranged in SVL from 1150-1580 mm, $140-175 \mathrm{~mm}$ in tail length, and $800-1600 \mathrm{~g}$. All males had well-developed pelvic spurs, enlarged turgid testis, and considerable amounts of lipid reserves.

At 22:00 h, on 20 May 2013, we discovered a pair of Cuban Boas in copula inside a bat cave (22 $24^{\circ} 16^{\prime \prime} \mathrm{N}, 79^{\circ} 23^{\prime} 25^{\prime \prime} \mathrm{W}, 75 \mathrm{~m}$ a.s.1.) at "Lomas las Tasajeras", Yaguajay, Sancti-Spíritus Province. The female SVL was $1300 \mathrm{~mm}$ (155 $\mathrm{mm}$ tail length, $1700 \mathrm{~g}$ ) and the male SVL was $1520 \mathrm{~mm}$ (210 mm tail length, $1500 \mathrm{~g})$.

On 14 July 2013, we collected a pregnant female Chilabothrus angulifer (1320 mm SVL, $160 \mathrm{~mm}$ tail length, $1730 \mathrm{~g}$ ) at "Las Breas" path (22024'16" N, 79²3'25" W, 75 m a.s.l.), Camajuaní, Villa Clara Province. On 4 November 2013, it gave birth to 3 neonates in captivity;
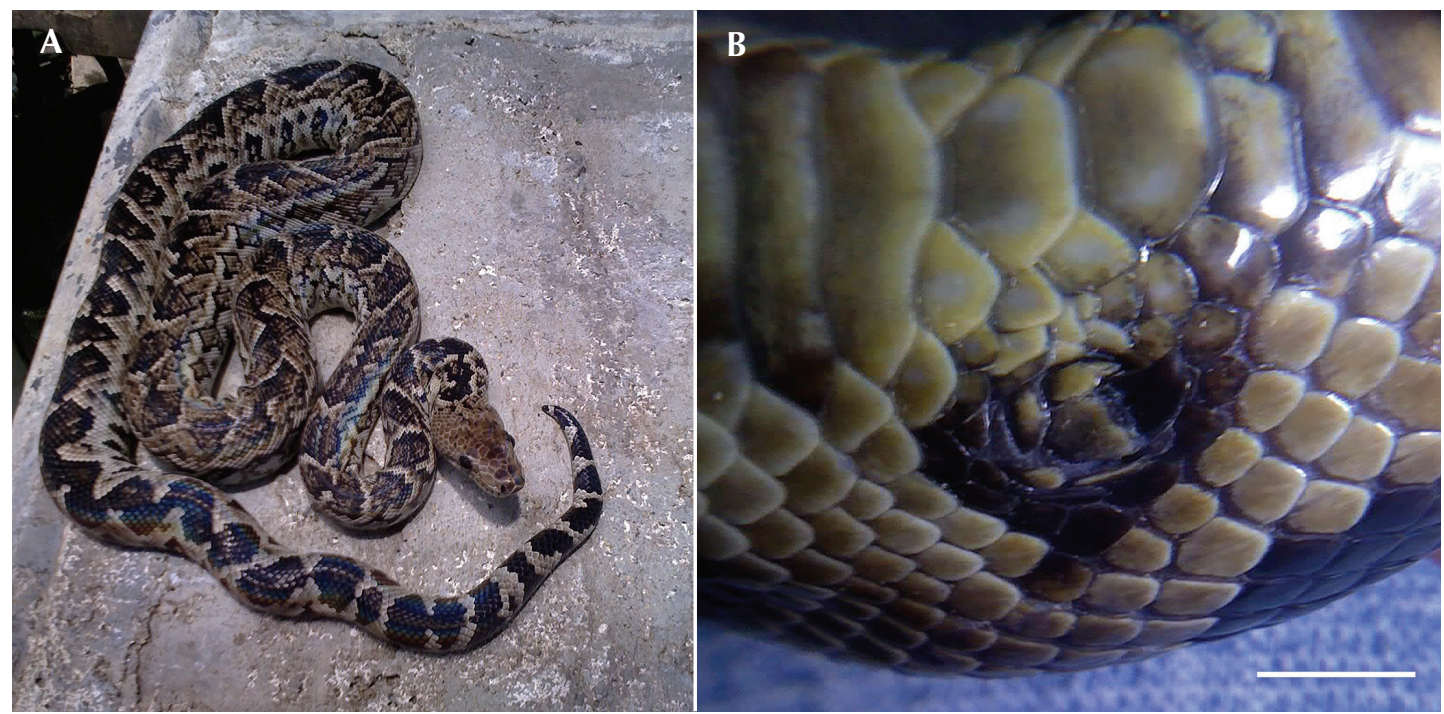

Figure 1. Mature male Chilabothrus angulifer collected at Cariblanca, Fomento, Sancti Spíritus Province (A), and details of the vent region showing pelvic spur $(\mathbf{B})$. Scale bar $=5 \mathrm{~mm}$. Photographs by TMRC. 

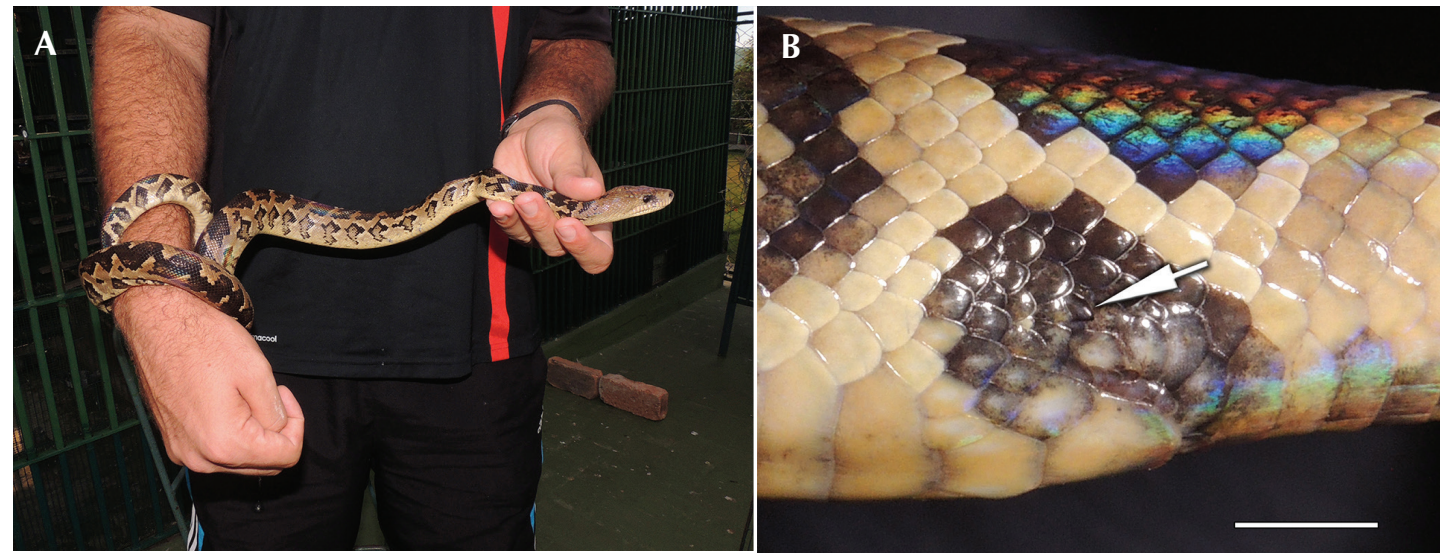

Figure 2. Female Chilabothrus angulifer (995 mm SVL, $550 \mathrm{~g}$ ) approaching the size of the smaller males reported in this paper (A), with detail of lateral vent region (B) depicting reduced pelvic spurs (arrow). Scale bar $=5 \mathrm{~mm}$. Photographs by TMRC.

they ranged in SVL from $617-635 \mathrm{~mm}, 57-65$ $\mathrm{mm}$ in tail length, and 141-150 g.

At 08:30 h, on 30 March 2014, we found a freshly road-killed male Cuban Boa (1180 mm SVL, $145 \mathrm{~mm}$ tail length, $833 \mathrm{~g}$ ) (Figure 3A) at the Cienfuegos Botanical Garden $\left(22^{\circ} 07^{\prime} 36^{\prime \prime} \mathrm{N}\right.$, 80 19'51" W, 70 m a.s.1.), Cienfuegos Province. A thorough examination of the snake revealed well-developed pelvic spurs (Figure 3B), considerable amount of lipid reserves (42 $\mathrm{g}=$ $5 \%$ of body mass) (Figure 3C), and enlarged turgid testes (Figure 3D). These features suggested sexual maturation, which we confirmed after observing sperm cells in the cross sections from the testis and epididymis. The latter structure in particular showed great amount of sperm and secretion in the lumen (Figure 4).

Seven individuals from the Ecological Reserve "Mogotes de Jumagua" were recaptured once $\left(2\right.$ in the $3^{\text {rd }}$ month, 3 in the $6^{\text {th }}$ month, 1 in the $9^{\text {th }}$ month, and 1 in the $12^{\text {th }}$ month), and one was recaptured twice $\left(3^{\text {rd }}\right.$ and $9^{\text {th }}$ month, respectively). They increased from $7-20 \mathrm{~mm}$ in length per month $($ mean $=14.8 \pm 4.1 \mathrm{~mm})$. All the above cases are summarized in the Table 1.

\section{Discussion}

Ectotherms allocate a high proportion of their energy budget to growth (e.g., Parry 1983, Peterson et al. 1999). However, free-living, nonreproductive reptiles must partition their energy budgets in other aspects besides growth, such as a more intense mobility during foraging periods, competition, defense, and interaction with unpredictable physical environments like temperature and relative humidity (e.g., Vitt and Caldwell 2014). Thus, it is expected that wild animals show lower growth rates than those under captivity conditions, subjected to a forced sedentary lifestyle and usually not affected by the above mentioned factors. Also, differential hunting success must be a crucial factor affecting growth of free-living immature Cuban Boas (P. J. Tolson, in litt., 14-XI-2012). The average increase in total length of the Cuban Boas recaptured in nature did not exceed $15 \mathrm{~mm}$ per month, in contrast to the near $30 \mathrm{~mm}$ per month showed by some immature captive boas under maximized food intake (Tolson 1992, Tolson and Henderson 1993, Morell et al. 1998, PoloLeal and Moreno 2007). Notoriously, those eight 

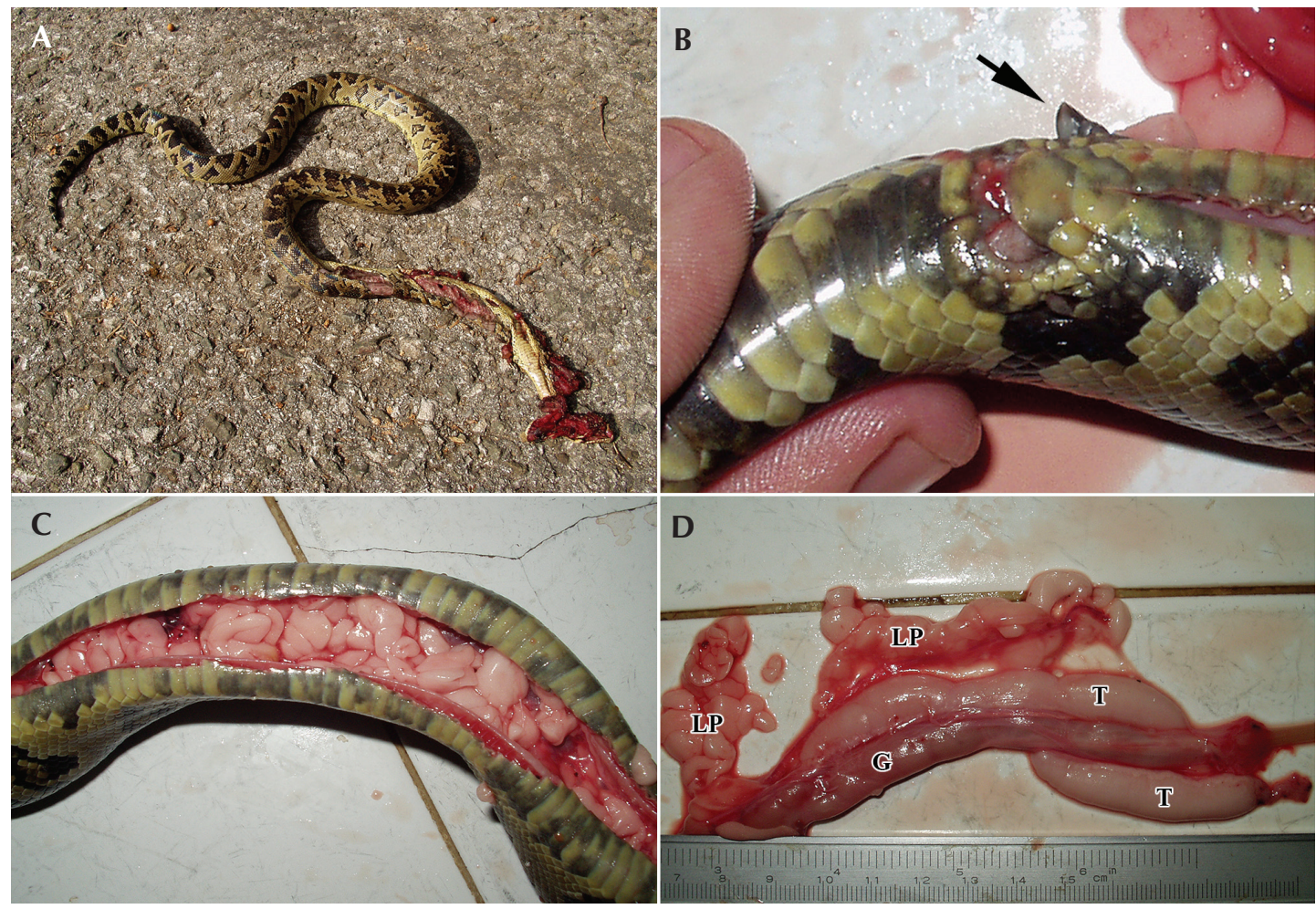

Figure 3. Road-killed mature male Chilabothrus angulifer (A) from the Cienfuegos Botanical Garden, Cienfuegos Province, showing pelvic spurs (B, arrow), lipid packages inside the body cavity around mid-region $(\mathbf{C})$, and enlarged turgid testes (D): LP, lipid packages; G, gut; and T, testes. Photographs by TMRC.

Table 1. Summary of cases presented in this work with compelling evidences on sexual maturation of the Cuban Boa.

\begin{tabular}{|c|c|c|c|c|c|c|}
\hline \multirow{2}{*}{ Case } & \multicolumn{2}{|c|}{ Male (s) } & \multicolumn{2}{|c|}{ Female } & \multirow{2}{*}{ Evidence } & \multirow{2}{*}{ Date } \\
\hline & SVL (mm) & Mass (g) & SVL (mm) & Mass (g) & & \\
\hline 1 & 1272 & 900 & 2233 & 9525 & Successful fertilization & 30 March \\
\hline 2 & $1150-1580$ & $800-1600$ & 1520 & 1800 & Mating aggregation & 27 April \\
\hline 3 & 1520 & 1500 & 1300 & 1700 & Mating pair & 20 May \\
\hline 4 & - & - & 1320 & 1730 & Pregnant female & 14 July \\
\hline 5 & 1180 & 833 & - & - & Mature male & 30 March \\
\hline
\end{tabular}




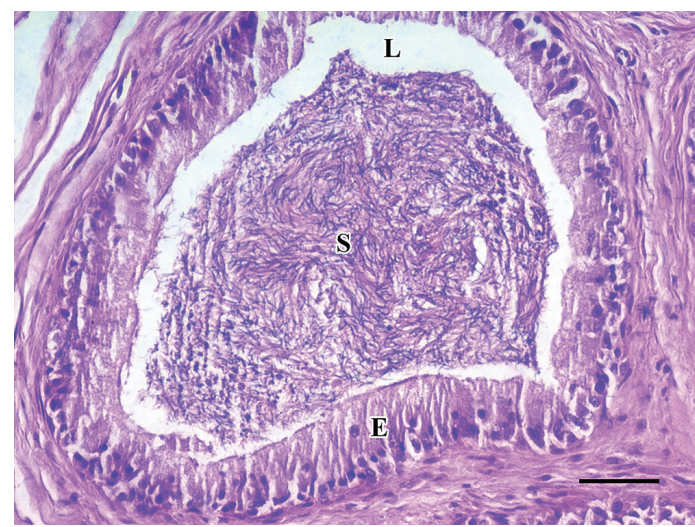

Figure 4. Cross sections of an epididymis duct of the road-killed male Chilabothrus angulifer from the Cienfuegos Botanical Garden, Cienfuegos Province: $\mathrm{E}=$ epithelium with columnar cells, $\mathrm{L}=$ lumen, and $\mathrm{S}=$ sperm cells embedded in secretions. Scale bar $=300 \mu \mathrm{m}$. Photograph by JTL.

wild boas recaptured inhabited a hot cave and surroundings, a suitable habitat with large concentration of bats and apparently good shelter conditions.

There is evidence that reproductive activity in the genus Chilabothrus is seasonal (Vitt and Vangilder 1983, Tolson and Henderson 1993), which is consistent with most boid snakes (e.g., Fitch 1982, Vitt and Vangilder 1983, Bertona and Chiaraviglio 2003, Pizzatto et al. 2006a, Pizzatto and Marques 2007, Rivas et al. 2007; review in Reed and Rodda 2009). Courtship and mating in wild populations of $C$. angulifer occurs mainly at the onset of the rainy season, from April to June (e.g., Tolson and Henderson 1993, Morell et al. 1998, this paper). This allows embryos to develop during warmer months (Tolson and Henderson 1993), probably the most suitable period for thermoregulatory activity of gravid females. Parturition occurs frequently from September to December, with most in October and November (e.g., Tolson and Henderson 1993, Morell et al. 1998, this paper). This synchronous appearance of neonates during the late rainy season and early dry season ("fall and early winter") could seems controversial regarding most West Indian reptiles, which normally born at the beginning or during the core of the wet season ("spring and summer"; see Henderson and Powell 2009 for a review). However, due to the large size of neonate Cuban Boas (usually exceeding $600 \mathrm{~mm} \mathrm{SVL}$ and 150 g; Tolson 1992, Polo-Leal and Moreno 2007, Morell 2009, this paper), they can consume relatively large prey almost immediately after birth, including small endotherms such as bats (Rodríguez-Cabrera et al. 2015), and probably rodents and birds of equivalent size. This would translate in a year-round food supply for this age class, which would not necessarily limit births during a time of the year when insects, hatchling anoles and small frogs are plentiful and thus determine the most favorable period for most reptiles in the region (see Henderson and Powell 2009 for review). Also, yolk reserves at birth must allow neonate Cuban Boas to withstand several months of starvation, without any apparent sign of health damage other than mass loss even after seven months (T. M. RodríguezCabrera pers. obs. in captivity), a considerable span through which the probability to find a meal should be high.

This seasonal pattern is consistent with that observed in most viviparous snakes (Boidae, Tropidophiidae) in the West Indies (for review see Tolson and Henderson 1993, Henderson and Powell 2009), which suggests that natural selection might has favored seasonality prioritizing the occurrence of gestation during warmer months (temperature is a critical factor for embryos development). Despite year-round air temperatures in Cuba could seem high enough as to ensure adequate rates of embryonic development in Antillean viviparous snakes (Tolson and Henderson 1993), the synchrony observed in parturitions suggest that even the small differences between seasons have significant effects in animal behavior and reproductive cycles. Mean air temperatures in Cuba can drop more than $5^{\circ} \mathrm{C}$ during the coolest 
months of the dry season (December-February), although extreme values below $10^{\circ} \mathrm{C}$ in winter and above $35^{\circ} \mathrm{C}$ in summer are not rare (data provided by the Instituto de Meteorología of Cuba, at the request of the authors), triggering even winter aggregation in highly territorial reptiles like anoles (Marrero et al. 2016). Also, despite hot caves (with year-round favorable and stable thermal conditions) are widespread in Cuba (Longueira 2006), we consider they are not representative enough of the species range and thus insufficient to shelter females from all subpopulations during pregnancy, being unlikely that this caves have functioned as selective pressure toward a trend for females to reproduce year-round using this sites for thermoregulation.

Some of the males described herein were by far the smallest reported for reproductivelymature Chilabothrus angulifer. Whether such small males found engaged in breeding aggregations could mate successfully or not is open to question; nonetheless, we consider the fact that they allocated energy to reproductive activity as enough evidence of sexual maturation. One of these males was indeed very small (i.e., $1150 \mathrm{~mm}$ SVL, $800 \mathrm{~g}$ ), being probably near the lowest limit of breeding size for a male of this species. All these small males showed welldeveloped pelvic spurs, enlarged and turgid testis and great amount of lipid reserves (see also Pizzatto et al. 2006b), similar to the individual from the Cienfuegos Botanical Garden, on which we confirmed sperm production (Figure 3). Finally, the behavior observed in the male collected at Cariblanca (active by day) is consistent with the increased restlessness described for captive mature males at the onset of the reproductive season (Tolson 1992, 1994).

Gundlach (1880) commented that some male Cuban Boas aggregate around a single female during the breeding season, which he hypothesized might has led to a folk legend on a snake with multiple heads. This behavior was corroborated by other authors in captivity (Tolson 1983, Tolson and Henderson 1993) and by us in the wild (this paper), although it is common to hear farmers and other field people in Cuba to talk about this phenomenon. Breeding or mating aggregations are relatively common in snakes (e.g., Bertona and Chiaraviglio 2003, Rivas et al. 2007, Jellen and Aldridge 2011, Nilson 2011). Other West Indian boids for which this behavior has been reported in the wild are the Saint Lucia boa, Boa constrictor orophias (note that some authors consider Boa populations from the Lesser Antilles as full species) and the congeneric Jamaican boa, Chilabothrus subflavus (Gosse 1851, Henderson and Powell 2009, Henderson and Breuil 2012). Teubner (1986) and Tolson and Teubner (1987) found that in captive Haitian boas (C. striatus) mean plasma testosterone levels of alpha-males (usually of larger size) increase with male-male agonistic interactions, whereas plasma testosterone levels of smaller males tend to decrease. This suggests that mating success of young mature males during their first breeding season might be lower, particularly while engaging in ritualized combat with larger males during breeding aggregations. Nonetheless, the optimum size required for a male to succeed in male-male combat or in interference competition is independent of the reproductive condition (maturity) of its gonads, even the looser (usually smaller) males are sexually mature and thus potentially able to fertilize. Thus the chance of smaller mature males to reproduce will probably depend on the occurrence of larger and/or more competitive males around a particular female.

We have observed that female Cuban Boas apparently require higher sizes to reach the minimum required for sexual maturity, as seems the rule for viviparous snakes (Shine 1978, 1994, Tolson 1992, Tolson and Henderson 1993, Rivas and Burghardt 2001, 2005, Bertona and Chiaraviglio 2003). Shine (1978) suggested two main selective pressures as the causes for this female-biased sexual size dimorphism in snakes: (1) "female fecundity is proportional to body size, so natural selection may favor females that grow to a large size before reproducing"; and (2) "reproducing necessarily involves a 
female in a high energy expenditure, and risk, even if she only produces a small clutch" (see also review of Rivas and Burghardt 2001). Female fecundity is proportional to coelomic capacity, which allows larger clutches with greater possibility of larger offspring, thus with the subsequent greater chances of survival (Rivas and Burghardt 2001). Male reproductive maturity does not strongly depend on body size, mainly because of the minor cost of spermatogenesis (Shine 1978). Also, a very large body size in males could be disadvantageous because of the higher energetic cost for locomotion when tracking potential mates during the breeding season (Rivas and Burghardt 2001). Rivas and Burghardt (2001) also reasoned that there must be selective pressures toward a male local size optimum, where they are large enough as to succeed in male-male combats in the breeding aggregation, and yet small enough as to be distinguished from breeding females. These last authors also concluded that a large size would be selected in male snake species that do not show male-male combat during breeding aggregations. They mentioned that sexual size dimorphism could be the key for sex identification where a chemosensorial system is useless because both males and female in the breeding ball are impregnated in the same pheromones. However, both highly ritualized male-male combats (and/ or intense agonistic behavior) and interference competition during breeding aggregations have been reported in the Cuban Boa (Tolson 1983, Tolson and Henderson 1993, this paper). Therefore, the optimum body size in males of this species appears to be selected by a combination of both types of selective pressures.

Reproduction imposes a high energetic demand to females of viviparous snakes, mainly due to catabolism and mobilization of a considerable amount of fat and structural protein (Lourdais et al. 2002, 2004, 2005). This can compromise seriously the performance of postreproductive females, to the point that many of them have to reproduce at least biennially in order to guarantee a proper recovery (fat stores and functional muscle) before the next reproduction (Lourdais et al. 2004). Tolson and Teubner (1987) and Petersen et al. (2015) have found evidence for free-ranging female Cuban Boas to reproduce at least biennially, which suggest that this species invest a large proportion of energy during pregnancy (see Bertona and Chiaraviglio 2003 for similar results with Boa constrictor occidentalis). So, there is a minimum optimum size required for females of each snake species at first reproduction, and that for the Cuban Boa seems to be around 1300-1400 mm SVL. A small female Cuban Boa (1460 mm SVL) was mentioned by B. R. Sheplan and A. Schwartz (in Tolson and Henderson 1993) as already containing three embryos on early August, but two of the females (1300 and 1320 $\mathrm{mm}$ SVL, respectively) reported herein represent the smallest mature females known for this species.

Therefore, a wild Cuban Boa with a SVL around $600 \mathrm{~mm}$ at birth and assuming a subsequent average growth rate of about $15 \mathrm{~mm}$ in length per month, could be near the size attained by the smaller reproductively-mature male reported herein (1150 mm SVL) by the spring following the third year of age. A female will require at least two more years and a larger size (ca. $1300 \mathrm{~mm} \mathrm{SVL}$ and > $1700 \mathrm{~g}$, minimum) to reproduce. Sex-dependent differential growth rates have not been demonstrated in immature Cuban Boas, but it probably occurs in adults as females can attain much larger sizes than males (T. M. Rodríguez-Cabrera, pers. obs.).

We do not exclude the possibility of other factors such as human predation pressure (selective killing of larger specimens), habitat (abiotic factors, food resources), and the incidence of introduced feral mammals (competition, predation) directly affecting the minimum size and age at which Cuban Boas reach sexual maturity. For example, Sasaki et al. (2008) found that populations of the Japanese Mamushi Pitviper, Gloydius blomhoffii (Boie, 1826) (Viperidae) can respond very fast to human predation pressure by significantly 
changing in body size, life-history traits (i.e., litter size, mean neonate SVL, mass loss in pregnant females), and antipredation behavior. But proving a similar trend in the Cuban Boa would require long-term investigations and extensive comparisons among populations subjected to different selective pressures, including captive (control) populations.

\section{Acknowledgments}

We are grateful to Peter J. Tolson, Ansel Fong, Alberto Puente-Rolón, and Armando R. Longueira for providing literature references and the productive exchange maintained. We also thank Jesús A. Rivas, Sheila Rodríguez, Félix Pazos, and anonymous reviewers for their useful comments on earlier versions of the manuscript. We finally acknowledge Emelyn Rodríguez, Humberto Vela, Martín Nuñez, Javier Pérez, Josue Irume, Roberto Martínez, and Roberto Martínez Jr. for field or lab assistance.

\section{References}

Bertona, M. and M. Chiaraviglio. 2003. Reproductive biology, mating aggregations, and sexual dimorphism of the Argentine boa constrictor (Boa constrictor occidentalis). Journal of Herpetology 37: 510-516.

Bloxam, Q. M. C. and S. Tonge. 1981. A comparison of reproduction in three species of Epicrates (Serpentes, Boidae) maintained at the Jersey Wildlife Preservation Trust. Dodo, Journal of Wildlife Preservation Trust 18: 64-74.

Day, M. and P. Tolson. 1996. Chilabothrus angulifer. The IUCN Red List of Threatened Species 1996: e. T7815A12852846. Electronic Database accessible at http: //dx.doi.org/10.2305/IUCN.UK.1996.RLTS. T7815A12852846.en. Downloaded on 01 February 2016. Captured on 31 July 2016.

Estrada, E. and M. Uribe. 2002. Atlas de Histología de Vertebrados. México. Universidad Nacional Autónoma de México. 222 pp.

Fitch, H. S. 1982. Reproductive cycles in tropical reptiles. Ocassional Papers of the Museum of Natural History, University of Kansas 96: 121-128.
Ganter, P. and G. Jollès. 1970. Histochimie Normale et Pathologique 2. Paris. Gauthier-Villars. 927 pp.

Gosse, P. H. 1851. A Naturalis's Sojourn in Jamaica. London. Longman, Brown, Green \& Longmans. 508 pp.

Gribbins, K. M. and J. L. Rheubert. 2011. The ophidian testis, spermatogenesis, and mature Spermatozoa. Pp. 183-264 in R. D. Aldridge and D. M. Sever (eds.), Reproductive Biology and Phylogeny of Snakes. Vol. 9. Enfield. Reproductive Biology and Phylogeny Series, Science Publishers.

Gundlach, J. C. 1880. Contribución a la Erpetología cubana. La Habana. G. Montiel. 99 pp.

Henderson, R. W. and M. Breuil. 2012. Lesser Antilles. Pp. 148-159 in R. Powell and R. W. Henderson (eds.), Island Lists of West Indian Amphibians and Reptiles. Bulletin of the Florida Museum of Natural History 51: $85-166$.

Henderson, R. W. and R. Powell. 2009. Natural History of West Indian Amphibians and Reptiles. Gainesville. University Press of Florida. 513 pp.

Huff, T. A. 1976. Breeding the Cuban Boa Epicrates angulifer at the Reptile Breeding Foundation. International Zoo Yearbook 16: 81-82.

Jellen, B. C. and R. D. Aldridge. 2011. Paternity patterns. Pp. 619-644 in R. D. Aldridge and D. M. Sever (eds.), Reproductive Biology and Phylogeny of Snakes. Vol. 9. Enfield. CRC Press.

Longueira, A. R. 2006. Composición, distribución y conservación de la fauna exclusiva de las cuevas de calor de Cuba. Unpublished M.Sc. Dissertation. Universidad de La Habana, Cuba.

Lourdais, O., X. Bonnet, R. Shine, D. DeNardo, G. Naulleau, and M. Guillon. 2002. Capital-breeding and reproductive effort in a variable environment: a longitudinal study of a viviparous snake. Journal of Animal Ecology 71: 470479.

Lourdais, O., F. Brischoux, D. DeNardo, and R. Shine. 2004. Protein catabolism in pregnant females (Epicrates cenchria maurus, Boidae) compromises musculature and performance after parturition. Journal of Comparative Physiology B 174: 383-391.

Lourdais, O., F. Brischoux, R. Shine, and X. Bonnet. 2005. Adaptive maternal cannibalism in snakes (Epicrates cenchria maurus, Boidae). Biological Journal of the Linnean Society 84: 767-774.

Marrero, R., J. Torres, and T. M. Rodríguez-Cabrera. 2016. Winter aggregation in Anolis equestris and A. lucius (Squamata: Dactyloidae), two territorial species from Cuba. Phyllomedusa 15: 181-186. 
Morell, E. 2009. Desarrollo y conducta del majá de Santa María en cautiverio, durante el primer año de vida. Cubazoo 20: 65-67.

Morell, E., R. Díaz Aguiar, and O. Alfonso Álvarez. 1998. El majá de Santa María (Epicrates angulifer): la boa de la mayor de las Antillas. Flora y Fauna 1: 40-42.

Murphy, J. B., D. G. Barker, and B. W. Tryon. 1978. Miscellaneous notes on the reproductive biology of reptiles. Eleven species of the family Boidae, genera Candoia, Corallus, Epicrates and Python. Journal of Herpetology 12: 385-390.

Nilson, G. 2011. History of reproductive studies on snakes. Pp. 1-17 in R. D. Aldridge and D. M. Sever (eds.), Reproductive Biology and Phylogeny of Snakes. Vol. 9. Enfield. CRC Press.

Nowinski, B. 1977. Voortplanting van de Cubaanse boa, Epicrates angulifer, in het terrarium. Lacerta 35: 144147.

Parry, G. D. 1983. The influence of the cost of growth on ectotherm metabolism. Journal of Theoretical Biology 101: 453-477.

Petersen, C., P. J. Tolson, and J. Jackson. 2015. Cuban Boa helps to maintain ecosystem balance at Guantánamo Bay. Currents, Summer 2015: 38-41.

Peterson, C. C., B. M. Walton, and A. F. Bennett. 1999. Metabolic costs of growth in free-living Garter Snakes and the energy budgets of ectotherms. Functional Ecolology 13: 500-507.

Pizzatto, L. and O. A. V. Marques. 2007. Reproductive ecology of boine snakes with emphasis on Brazilian species and a comparison to pythons. South American Journal of Herpetology 2: 107-122.

Pizzatto, L., S. M. de Almeida-Santos, and O. A. V. Marques. 2006a. Biologia reproductiva das serpentes brasileiras. Pp. 201-221 in M. E. de Oliveira and L. Barreto (eds.), Herpetología no Brasil, volume 2. Belo Horizonte. Sociedade Brasileira de Herpetologia.

Pizzatto, L., R. Haddad Manfio, and S. M. Almeida-Santos. 2006b. Male-male ritualized combat in the Brazilian rainbow boa, Epicrates cenchria crassus. Herpetological Bulletin 95: 16-20.

Polo-Leal, J. L. and L. V. Moreno. 2007. Reproducción y cría del majá de Santa María la boa de Cuba Epicrates angulifer (Bibron, 1843) en el Parque Zoológico Nacional de Cuba. Cubazoo 17: 33-38.

Polo-Leal, J. L. and T. M. Rodríguez-Cabrera. 2012. Epicrates angulifer. Pp. 160-164 in H. González Alonso, L. Rodríguez Schettino, A. Rodríguez, C. A. Mancina, and I. Ramos (eds.), Libro Rojo de los Vertebrados de Cuba. La Habana. Editorial Academia.

Reed, R. N. and G. H. Rodda. 2009. Giant Constrictors: Biological and Management Profiles and an Establishment Risk Assessment for Nine Large Species of Pythons, Anacondas, and the Boa constrictor. U.S. Geological Survey Open-File Report 2009-1202.

Reynolds, R. G., M. L. Niemiller, S. B. Hedges, A. Dornburg, A. R. Puente-Rolón, and L. J. Revell. 2013. Molecular phylogeny and historical biogeography of West Indian boid snakes (Chilabothrus). Molecular Phylogenetics and Evolution 68: 461-470.

Reynolds, R. G., A. R. Puente-Rolón, A. J. Geneva, K. J. Aviles-Rodriguez, and N. C. Herrmann. 2016. Discovery of a remarkable new boa from the Conception Island Bank, Bahamas. Breviora 549: 1-19.

Rivas, J. A. and G. M. Burghardt. 2001. Understanding sexual size dimorphism in snakes: wearing the snake's shoes. Animal Behavior 62: F1-F6.

Rivas, J. A. and G. M. Burghardt. 2005. Snake mating systems, behavior, and evolution: the revisionary implications of recent findings. Journal of Comparative Psychology 119: 447-454.

Rivas, J., M. C. Muñoz, G. M. Burghardt, and J. B. Thorbjarnarson. 2007. Sexual size dimorphism and the mating system of the Green Anaconda (Eunectes murinus). Pp. 313-325 in R. W. Henderson and R. Powell (eds.), Biology of the Boas and Pythons. Eagle Mountain. Eagle Mountain Publishing.

Rodríguez-Cabrera, T. M., J. Torres, and R. Marrero. 2015. At the lower size of snakes preying on bats in the West Indies: the Cuban Boa, Chilabothrus angulifer (Boidae). IRCF Reptiles \& Amphibians 22: 8-15.

Rodríguez-Robles, J. A., T. Jezkova, M. K. Fujita, P. J. Tolson, and M. A. García. 2015. Genetic divergence and diversity in the Mona and Virgin Islands Boas, Chilabothrus monensis (Epicrates monensis) (Serpentes: Boidae), West Indian snakes of special conservation concern. Molecular Phylogenetics and Evolution 88: $144-153$.

Rodríguez-Schettino, L., V. Rivalta González, and E. Pérez Rodríguez. 2010. Distribución regional y altitudinal de los reptiles de Cuba. Poeyana 498: 11-20.

Sasaki, K., S. F. Fox, and D. Duvall. 2008. Rapid evolution in the wild: changes in body size, life-history traits, and behavior in hunted populations of the Japanese mamushi snake. Conservation Biology 23: 93-102.

Shine, R. 1978. Growth rates and sexual maturation in six species of Australian elapid snakes. Herpetologica 34: $73-79$. 
Shine, R. 1994. Sexual size dimorphism in snakes revisited. Copeia 1994: 326-346.

Teubner, V. A. 1986. Endocrine and behavioral aspects of the reproductive cycle of the Haitian boa (Epicrates striatus). Unpublished Ph.D. Dissertation. University of Toledo, USA.

Tolson, P. J. 1980. Comparative reproductive behavior of four species of snakes in the boid genus Epicrates. Proceedings of the $4^{\text {th }}$ Reptile Symposium on Captive Propagation and Husbandry, Zoological Consortium, Inc., Thurmont, Maryland: 87-97.

Tolson, P. J. 1983. Captive propagation and husbandry of the Cuban Boa, Epicrates angulifer. Proceedings of the $6^{\text {th }}$ Reptile Symposium on Captive Propagation and Husbandry, Zoological Consortium, Inc., Thurmont, Maryland: 285-292.

Tolson, P. J. 1992. The reproductive biology of the Neotropical boid genus Epicrates (Serpentes: Boidae). Pp. 165-178 in W. C. Hamlett (ed.), Reproductive Biology of South American Vertebrates. New York. Springer-Verlag.

Tolson, P. J. 1994. The reproductive management of the insular species of Epicrates (Serpentes: Boidae) in captivity. Pp. 353-357 in J. B. Murphy, K. Adler, and J. T. Collins (eds.), Captive Management and Conservation of Amphibians and Reptiles. Vol. 11. Ithaca. Society for the Study of Amphibians and Reptiles, Contributions to Herpetology.

Tolson, P. J. and R. W. Henderson. 1993. The Natural History of West Indian Boas. Taunton. England. R \& A Publishing Limited. 125 pp.

Tolson, P. J. and V. A. Teubner. 1987. The role of social manipulation and environmental cycling in propagation of the boid genus Epicrates: lessons from the field and laboratory. American Association of Zoological Parks and Aquariums Regional Conference 1987: 606-613.

Torre, S. C. de la. 1985. Manual Básico de Microtecnia. $2^{\text {nd }}$ edition. La Habana. Editorial Pueblo y Educación. 193 pp.

UNEP-WCMC (Compilers). 2014. Checklist of CITES species. CITES Secretariat, Geneva, Switzerland, and UNEP-WCMC, Cambridge, United Kingdom. Accessible at http://www.checklist.cites.org. Downloaded on 20 July 2016.

Vitt, L. J. and J. P. Caldwell. 2014. Herpetology. An Introductory Biology of Amphibians and Reptiles. $4^{\text {th }}$ Edition. San Diego. Academic Press. 757 pp.

Vitt, L. J. and L. D. Vangilder. 1983. Ecology of a snake community in northeastern Brazil. Amphibia-Reptilia 4: 273-296.

Editor: Francisco L. Franco 